\title{
PERCEPTIONS AND PRACTICES REGARDING OCCUPATIONAL HAZARDS AND SAFETY MEASURES AMONG PRINTING WORKERS
}

\author{
By \\ Shama M. E. \\ From \\ Department of Health Administration and Behavioral Sciences \\ High Institute of Public Health - University of Alexandria
}

\begin{abstract}
:
Objective: The present cross sectional study aimed at assessing the practices and perceptions of workers in printing shops regarding occupational health hazards and safety measures applying the principles of the HBM. Methods: A total of 135 workers - directly involved in the printing industry- were recruited from 10 small sized printing shops in Alexandria, Egypt. An interview-led questionnaire was used to collect data regarding personal characteristics, workers' safety behaviors, perceived threat and perceived benefits and barriers related to safety behaviors. Results: The results showed that $82.2 \%$ and $92.6 \%$ of workers never wore overalls and gloves respectively. None of the workers used ear, eye or respiratory protectors. The majority of workers had low perception of risk of different health hazards they are exposed to. Only $17 \%$ had high threat perception and only $24.4 \%$ had high perception of benefit. The main barriers to adopting safety measures were interference with job performance, comfort issues, unavailability of PPE and not being trained. Conclusion: The study concluded that protective behaviors and perceptions among printing workers are extremely inadequate. The study highlights the importance of effective safety education and training to enhance workers perception of threat and benefit and decrease their perception of barriers. Thus adoption of safety behaviors can be achieved. Special attention should be directed towards young workers and those with lower education
\end{abstract}

Key Words: Printing workers, safety practices, health belief model, perceived threat, perceived benefit, perceived barriers 


\section{Introduction:}

Workers in printing shops are exposed to various occupational health hazards. Of the many hazards found in any print shop, the use of chemical substances must be rated among the most serious. A lot of chemical substances are used in print shops such as inks, solvents, acids and photo-chemicals. Adverse health effects from inhalation or skin contact include dermatitis, headaches, nausea and vomiting, difficult breathing, asthma and central nervous system depression. Chronic effects may include kidney and liver damage. Furthermore, various studies revealed an increased risk of cancer among workers in printing shops (International Labor organization, 2008). Actually many workers in small print shops have excessive exposures because these shops frequently have inadequate ventilation or other controls for the vapors. (CDC 2008).

Noise is considered to be another health hazard at print shops. Noise levels in printing shops may exceed 100 dBA (International Labor organization 2008). Excessive exposure to noise is a pervasive occupational hazard with many adverse effects, including elevated blood pressure, reduced performance, sleeping difficulties, annoyance and stress, tinnitus, noise-induced hearing loss and temporary threshold shift. Exposure to noise can be reduced in two ways, either by controlling or getting rid of noise at the source or by the use of suitable ear protection (Nelson, et al 2005).

Serious accidents occur in print shops. Printing presses were found to have a high ratio of accidents per number of hours used. Two of the most frequent causes of accidents are manual handling and contact with machinery. Investigation of these accidents reveals that failure to follow known safe work procedures contributes significantly in their cause. (Gardner, et al 1999).

One of the most significant characteristics of the printing industry is the large proportion of small enterprises. In USA, almost one half of all printing facilities have fewer than five employees and approximately 84 percent employ fewer than 20. (CNA, 2008) Small scale enterprises, usually defined as companies with $<50$ employees are a key issue in occupational health. Such companies share common characteristics such as poor resources, including monetary, personnel and technological resources; ageing and less flexibility for fitness for work, unfavorable factors for the promotion of occupational health. (Hoshuyama, et al 2007).

Promoting protective practices such as using personal protective equipments (PPE) and operating machinery safely could dramatically reduce the incidence of health problems and accidents among workers (International Labor organization, 2008, 
Al-Hemoud and Al-Asfoor, 2006). However, to change these practices it is necessary to understand the factors that cause them. To that effect, use can be made of behavioral models to investigate the factors related to safety practices among workers (DeJoy, 1996, Colémont and Van den Broucke 2008). One of the most influential models of preventive behavior change is the Health Belief Model (HBM). According to this model, people will follow a recommended protective behavior to prevent ill health condition if they perceive themselves as susceptible to the condition (perceived susceptibility), if they perceive that the condition would have potentially serious consequences (perceived severity), if they perceive the recommended behavior as beneficial in reducing the condition (perceived benefit) and that the benefit of this behavior outweigh the barriers that might hinder taking them (perceived barriers). Many behavioral scientists have found it useful to label the combination of susceptibility and severity as perceived threat. These perceptions form the basis of the HBM. (Janz et al 2002)

The aim of this study is to assess practices and perceptions of workers in printing shops regarding occupational health hazards and safety measures applying the principles of the HBM.

\section{Methodology:}

This cross sectional study was carried out in ten small printing shops (number of workers less than 30) in Alexandria, Egypt. All workers who were directly involved in the printing industry and agreed to fill the questionnaire were included in the study (a total of 135 workers). This study used an interviewer-led questionnaire; each interview took around 20 minutes. The questionnaire collected data about personal characteristics, history of occupational accidents, medical history of symptoms believed to be related to work hazards (dermatitis, bronchial asthma, back and hearing impairment), practicing safety measures, perception of threat, perception of benefit of safety practices and perception of barriers that inhibit compliance with safety practices.

Perception of threat was assessed by seven items rated at 3 point likert scale (agree, not sure and disagree). Six of these items included workers' perception of risk of exposure to solvents, ink, adhesives, noise, machines and UV rays from photocopiers and one assessed worker's perception of susceptibility to health problems as a result of working in the printing shop. For scoring purposes, each response was assigned a numerical value: $3=$ agree, $2=$ unsure and $1=$ disagree. Summing the numerical values 
of these items yielded a total score ranges from 7-21. The total score was categorized into 3 categories: high risk perception (1721), moderate risk perception (12-16) and low risk perception (7-11).

Perception of benefit was assessed by 9 items. Participants were requested to rate the importance with which they view different safety measures (e.g. wearing gloves, wearing overalls, ventilation of the workplace). A numerical value was assigned to each response: $3=$ important, $2=$ unsure and $1=$ not important. A total score was calculated by summing the numerical values of these items. The score ranged from 9-21 and was categorized into 3 categories: high perception of benefit (22-27), moderate perception of benefit (16-21) and low perception of benefit (9-15).

Perception of barriers was assessed by one question asking about the barriers that hinder using safety measure. Those who mentioned no barriers were considered having low perception of barriers; those who mentioned one barrier were considered having moderate barrier perception while those who mentioned more than one barrier were considered having high barrier perception.

\section{Data analysis:}

Data were entered into a Statistics
Package for Social scientists for windows 10 (SPSS) and frequencies were calculated for all variables. $\mathrm{X}^{2}$ analysis was the test of significance used to determine factors related to workers' perceptions. The determinants of workers' compliance with safety measures could not be investigated in this study because the sample was almost homogeneous regarding non-compliance.

\section{Results:}

\section{Characteristics of workers:}

The workforce was identified to be predominantly male as females formed only $3 \%$ of the sample. Age of workers ranged between 14 and 67 years (mean 34.5 years \pm 12.5 ) with $30.4 \%$ aged between 18 and 29 years and $30.4 \%$ aged 40 years and over. Children (below 18) represented $10.4 \%$ of the sample. More than half of the sample had less than 9 years education and $14.1 \%$ were illiterate. Married workers represented around two thirds of the sample. Of the 135 workers, $37.8 \%$ had worked in printing industry for 10-19 years and quarter of them had worked for 20 years or more. Working hours per day ranged between 8 and 12 with $63.3 \%$ of the sample were working 8 hours daily and $34.1 \%$ for 12 hours. One quarter of the sample reported receiving occupational health education provided by safety officer (Table 1) 
Symptoms of diseases and occupational injuries:

A total of 26 workers (19.3\%) self reported having skin complaint. Reported symptoms included dry skin, itching and rash. Back pain was reported by $13.3 \%$ of workers and respiratory symptoms were reported by $8.9 \%$. Respiratory symptoms included chronic cough with sputum, occasional wheezes, and a physician diagnosis of asthma. Only $4.4 \%$ complained of hearing impairment. (Table 2)

Injuries were reported by $29 \%$ of the workers, $10 \%$ of workers reported resulted permanent impairment (Figure 1). Finger amputation was the most common injury representing $30.8 \%$ of all injuries followed by upper arm bruise/fracture/cuts (28.2\%), strain back and foot bruise/fracture (15.4\%). One worker reported below elbow amputation. (Table 3)

\section{Workers' compliance to safety measures:}

The results revealed that all the workers had never used respiratory protective equipment, eye protective equipment or ear protective equipment and $92.6 \%$ had never worn gloves when dealing with chemicals. Workers who had never worn overalls represented $82.2 \%$ of the sample. Furthermore, the great majority of workers did not follow other safety measure e.g. eating in the workplace $(98.5 \%)$, and not making sure that windows are opened for good ventilation $(94.8 \%)$. Table 4

\section{Workers' perception of risk:}

When asked about the risk of different health hazards, only 5.1\%, 5.9\% and 5.9\% had high perception of risk of solvents, adhesives and noise respectively. These percentages increased to $7.5 \%, 11.1 \%$ and $20.7 \%$ for the risk of ink, ultraviolet rays and injuries from machines respectively. Table 5

Regarding perception of threat, only $17.0 \%$ of workers were considered having high perception of threat and $38.5 \%$ were considered having moderate threat perception. The results revealed that threat perception increases significantly with increasing workers' educational level $\left(\mathrm{X}^{2}=12.56\right.$, $\mathrm{P}=0.014)$ and with increasing workers' age $\left(\mathrm{X}^{2}=19.40, \mathrm{P}=0.004\right)$. Table 6 .

\section{Workers perception of benefit of and} barriers to adoption of safety measures:

Only one quarter of the sample perceived adoption of safety measures as beneficial, while around half of the workers had low perception of benefit. High perception of benefit was found to be significantly associated with increased level of education $\left(X^{2}=10.44, P=0.034\right)$ and with receiving occupational health education classes $\left(\mathrm{X}^{2}=\right.$ 14.93, $\mathrm{P}=0.001)$.Table 7. 
The most commonly mentioned barriers for adopting safety measures were interference with job performance (mentioned by $28.1 \%$ of workers), comfort issues either psychological or physical (20.7\%), unavailability of personal protective equipments (PPE) (19.3\%) and not being trained on the use PPE. Table 8 .
Concerning the total perception of barriers, only $17 \%$ of the sample had high perception of barriers. Perception of barriers was found to be increasing with increasing length of working in print shops; however this relation was not statistically significant $\left(X^{2}=9.24, P=0.055\right)$. Table 9 .

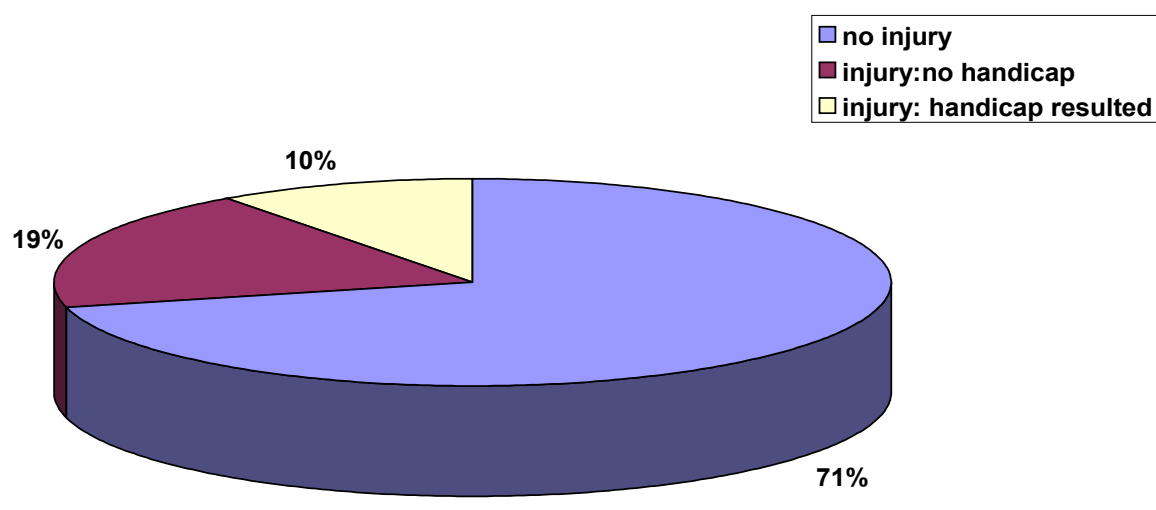

Figure 1: injuries and resulted permanent impairment in printers' workers 
Table 1: General characteristics of the sample

\begin{tabular}{|c|c|c|}
\hline Personal characteristics & No (135) & $\%$ \\
\hline $\begin{array}{l}\text { Age } \\
<18 \text { years } \\
18- \\
30- \\
40-\end{array}$ & $\begin{array}{l}14 \\
41 \\
39 \\
41\end{array}$ & $\begin{array}{l}10.4 \\
30.4 \\
28.9 \\
30.4\end{array}$ \\
\hline Mean \pm SD 34.5 years \pm 12.5 & & \\
\hline $\begin{array}{l}\text { Sex } \\
\text { Males } \\
\text { females }\end{array}$ & $\begin{array}{c}131 \\
4\end{array}$ & $\begin{array}{c}97.0 \\
3.0\end{array}$ \\
\hline $\begin{array}{l}\text { Marital status } \\
\text { Married } \\
\text { single }\end{array}$ & $\begin{array}{l}91 \\
44\end{array}$ & $\begin{array}{l}67.4 \\
32.6\end{array}$ \\
\hline $\begin{array}{l}\text { Educational level } \\
\text { Illiterate } \\
<9 \text { years education } \\
9-12 \text { years education } \\
>12 \text { years education }\end{array}$ & $\begin{array}{l}19 \\
75 \\
29 \\
12\end{array}$ & $\begin{array}{c}14.1 \\
55.6 \\
21.5 \\
8.9\end{array}$ \\
\hline $\begin{array}{l}\text { length of work in print shops } \\
<10 \text { years } \\
10 \text { years- } \\
20 \text { years- }\end{array}$ & $\begin{array}{l}49 \\
51 \\
35\end{array}$ & $\begin{array}{l}36.3 \\
37.8 \\
25.9\end{array}$ \\
\hline $\begin{array}{l}\text { Working hours/day: } \\
8 \text { hours } \\
10 \text { hours } \\
12 \text { hours }\end{array}$ & $\begin{array}{c}85 \\
4 \\
46\end{array}$ & $\begin{array}{r}63.0 \\
3.0 \\
34.1\end{array}$ \\
\hline $\begin{array}{l}\text { Receiving health education/training } \\
\text { Yes } \\
\text { No }\end{array}$ & $\begin{array}{c}34 \\
101\end{array}$ & $\begin{array}{l}25.2 \\
74.8\end{array}$ \\
\hline
\end{tabular}


Table 2: Symptoms of occupational diseases among printers' workers

\begin{tabular}{|l|c|c|}
\hline Symptoms & Number (135) & \% \\
\hline Skin symptoms & 26 & 19.3 \\
Back pain & 18 & 13.3 \\
Respiratory symptoms & 12 & 8.9 \\
Hearing impairment & 6 & 4.4 \\
\hline
\end{tabular}

Table 3: Type of accidents among printers' workers

\begin{tabular}{|l|c|c|}
\hline Symptoms & Number & $\boldsymbol{\%}$ \\
\hline Finger amputation & 12 & 30.8 \\
Upper arm bruise/fractures/cuts & 11 & 28.2 \\
Strain back & 6 & 15.4 \\
Foot bruise/fracture & 6 & 15.4 \\
Face injury & 3 & 7.7 \\
Below elbow amputation & 1 & 2.6 \\
\hline Total accidents & 39 & 100.0 \\
\hline
\end{tabular}


Table 4: Workers' non safety practices.

\begin{tabular}{|l|c|c|}
\hline Non safety practice & No (133) & \% \\
\hline Never wore overalls & 111 & 82.2 \\
\hline Never used gloves & 125 & 92.6 \\
\hline Never used ear protection & 135 & 100.0 \\
\hline Never wore goggles/glasses & 135 & 100.0 \\
\hline Never use respiratory protective equipment & 135 & 100.0 \\
\hline Not open windows for good ventilation & 128 & 94.8 \\
\hline Eating while working in the print shop & 133 & 98.5 \\
\hline
\end{tabular}

Table 5: Workers' perception of risk of different hazards.

\begin{tabular}{|l|c|c|c|}
\hline \multirow{2}{*}{ Health hazards } & \multicolumn{3}{|c|}{ Perception of risk } \\
\cline { 2 - 4 } & $\begin{array}{c}\text { Low } \\
\text { No }(\%)\end{array}$ & $\begin{array}{c}\text { Moderate } \\
\text { No ( \% })\end{array}$ & $\begin{array}{c}\text { High } \\
\text { No ( \% })\end{array}$ \\
\hline Solvents $(\mathrm{n}=135)$ & $81(60.0)$ & $47(34.8)$ & $7(5.2)$ \\
\hline Ink (n=135) & $69(51.1)$ & $56(41.5)$ & $10(7.4)$ \\
\hline Adhesives/glue $(\mathrm{n}=135)$ & $77(57.0)$ & $50(37.0)$ & $8(5.9)$ \\
\hline Noise $(\mathrm{n}=135)$ & $73(54.1)$ & $54(40.0)$ & $8(5.9)$ \\
\hline Injury from machines $(\mathrm{n}=135)$ & $65(48.1)$ & $42(31.1)$ & $28(20.7)$ \\
\hline UV rays from photocopiers $(\mathrm{n}=135)$ & $80(59.3)$ & $40(29.6)$ & $15(11.1)$ \\
\hline
\end{tabular}


Table 6: Factors related to workers' perception of threat.

\begin{tabular}{|c|c|c|c|}
\hline \multirow[b]{2}{*}{ Personal characteristics } & \multicolumn{3}{|c|}{ Perception of threat } \\
\hline & $\begin{array}{c}\text { Low } \\
\text { No }(\%)\end{array}$ & $\begin{array}{c}\text { Moderate } \\
\text { No ( \% ) }\end{array}$ & $\begin{array}{c}\text { High } \\
\text { No }(\%)\end{array}$ \\
\hline \multicolumn{4}{|l|}{ Age $\quad\left(X^{2}=19.40\right)^{* *}$} \\
\hline$<18$ years $(\mathrm{n}=14)$ & $12(85.7)$ & $1(7.1)$ & $1(7.1)$ \\
\hline $18-\quad(n=41)$ & $17(41.5)$ & $13(31.7)$ & $11(26.8)$ \\
\hline$(n=39)$ & $17(43.6)$ & $20(51.3)$ & $2(5.1)$ \\
\hline $40-\quad(n=41)$ & $14(34.1)$ & $18(43.9)$ & $9(22.0)$ \\
\hline \multicolumn{4}{|l|}{ Education $\left(X^{2}=12.56\right)^{*}$} \\
\hline Illiterate $\quad(n=19)$ & $14(73.7)$ & $4(21.1)$ & $1(5.3)$ \\
\hline$<9$ years education $\quad(n=75)$ & $32(42.7)$ & $33(44.0)$ & $10(13.3)$ \\
\hline$\geq 9$ years education $\quad(n=41)$ & $14(34.1)$ & $15(36.6)$ & $12(29.3)$ \\
\hline \multicolumn{4}{|l|}{ Length of working in the print shop } \\
\hline$<10$ years $(n=49)$ & $24(49.0)$ & $14(28.6)$ & $11(22.4)$ \\
\hline 10 years- $\quad(n=51)$ & $21(41.2)$ & $20(39.2)$ & $10(19.6)$ \\
\hline 20 years- $\quad(n=35)$ & $15(42.9)$ & $18(51.4)$ & $2(5.7)$ \\
\hline \multicolumn{4}{|l|}{ Receiving health education } \\
\hline Yes $\quad(n=34)$ & $15(44.1)$ & $15(44.1)$ & $4(11.8)$ \\
\hline$(n=101)$ & $45(44.6)$ & $37(36.6)$ & $19(18.8)$ \\
\hline Total $(n=135)$ & $60(44.4)$ & $52(38.5)$ & $23(17.0)$ \\
\hline
\end{tabular}

$* * \mathrm{P}=0.001$

$* \mathrm{P}=0.014$ 
Table 7: Factors related to workers' perception of benefits of protective behaviors.

\begin{tabular}{|c|c|c|c|}
\hline \multirow[b]{2}{*}{ Personal characteristics } & \multicolumn{3}{|c|}{ Perception of benefit } \\
\hline & $\begin{array}{c}\text { Low } \\
\text { No }(\%)\end{array}$ & $\begin{array}{l}\text { Moderate } \\
\text { No ( \% ) }\end{array}$ & $\begin{array}{c}\text { High } \\
\text { No }(\%)\end{array}$ \\
\hline Age & & & \\
\hline$<18$ years $(n=14)$ & $9(64.3)$ & $4(28.6)$ & $1(7.1)$ \\
\hline $18-\quad(n=41)$ & $22(53.7)$ & $9(22.0)$ & $10(24.4)$ \\
\hline $30-\quad(n=39)$ & $16(41.0)$ & $10(25.6)$ & $13(33.3)$ \\
\hline $40-\quad(n=41)$ & $19(46.3)$ & $13(31.7)$ & $9(22.0)$ \\
\hline Education $\left(X^{2}=10.44\right) *$ & & & \\
\hline Illiterate $\quad(n=19)$ & $12(63.2)$ & $5(26.3)$ & $2(10.5)$ \\
\hline$<9$ years education $\quad(n=75)$ & $40(53.3)$ & $21(28.0)$ & $14(18.7)$ \\
\hline$\geq 9$ years education $\quad(n=41)$ & $14(34.1)$ & $10(24.4)$ & $17(41.5)$ \\
\hline Length of working in the print shop & & & \\
\hline$<10$ years $(n=49)$ & $26(53.1)$ & $11(22.4)$ & $12(24.5)$ \\
\hline 10 years- $\quad(n=51)$ & $24(47.1)$ & $14(27.5)$ & $13(25.5)$ \\
\hline 20 years- $\quad(n=35)$ & $16(45.7)$ & $11(31.4)$ & $8(22.9)$ \\
\hline Receiving health education $\left(X^{2}=14.93\right) * *$ & & & \\
\hline Yes $\quad(n=34)$ & $7(20.6)$ & $13(38.2)$ & $14(41.2)$ \\
\hline No $\quad(n=101)$ & $59(58.4)$ & $23(22.8)$ & $19(18.8)$ \\
\hline Total $(n=135)$ & $66(48.9)$ & $36(26.7)$ & $33(24.4)$ \\
\hline
\end{tabular}

$* \mathrm{P}=0.034 \quad * * \mathrm{P}=0.001$ 
Shama M.E.

Table 8: Barriers to compliance with protective behaviors

\begin{tabular}{|c|c|c|}
\hline Barriers & Number (135) & Percentage \\
\hline $\begin{array}{ll}\text { - } & \text { Interference with job performance. } \\
\text { - } & \text { Comfort issues. } \\
\text { - } & \text { Unavailability of PPE. } \\
\text { - } & \text { Not trained for their use. }\end{array}$ & $\begin{array}{l}38 \\
28 \\
26 \\
24\end{array}$ & $\begin{array}{l}28.1 \\
20.7 \\
19.3 \\
17.8\end{array}$ \\
\hline
\end{tabular}

Table 9: factors related to perception of barriers to adopting protective behaviors

\begin{tabular}{|c|c|c|c|}
\hline \multirow[b]{2}{*}{ Variables } & \multicolumn{3}{|c|}{ Perception of barriers } \\
\hline & $\begin{array}{c}\text { Low } \\
\text { No (\%) }\end{array}$ & $\begin{array}{c}\text { Moderate } \\
\text { No ( \% ) }\end{array}$ & $\begin{array}{c}\text { High } \\
\text { No (\%) }\end{array}$ \\
\hline Age & & & \\
\hline$<18$ years $(\mathrm{n}=14)$ & $8(57.1)$ & $5(35.7)$ & $1(7.1)$ \\
\hline$(\mathrm{n}=41)$ & $15(36.6)$ & $21(51.2)$ & $5(12.2)$ \\
\hline $30-\quad(n=39)$ & $13(33.3)$ & $13(33.3)$ & $13(33.3)$ \\
\hline$(n=41)$ & $11(26.8)$ & $21(51.2)$ & $9(22.0)$ \\
\hline Education & & & \\
\hline Illiterate $\quad(n=19)$ & $4(21.1)$ & $11(57.9)$ & $4(21.1)$ \\
\hline$<9$ years education $(\mathrm{n}=75)$ & $28(37.3)$ & $30(40.0)$ & $17(22.7)$ \\
\hline$\geq 9$ years education $\quad(n=41)$ & $15(36.6)$ & $19(46.3)$ & $7(17.1)$ \\
\hline Length of working in the print shop & & & \\
\hline$<10$ years $(n=49)$ & $20(40.8)$ & $24(49.0)$ & $5(10.2)$ \\
\hline 10 years- $\quad(n=51)$ & $17(33.3)$ & $24(47.1)$ & $10(19.6)$ \\
\hline 20 years- $\quad(n=35)$ & $10(28.6)$ & $12(34.3)$ & $13(37.1)$ \\
\hline Receiving health education & & & \\
\hline Yes $\quad(n=34)$ & $13(38.2)$ & $16(47.1)$ & $5(14.7)$ \\
\hline No $\quad(n=101)$ & $34(33.7)$ & $44(43.6)$ & $23(22.8)$ \\
\hline Total $(n=135)$ & $47(34.8)$ & $60(44.4)$ & $28(20.7)$ \\
\hline
\end{tabular}




\section{Discussion:}

The results of this study showed that $10.4 \%$ of the study sample was in the age group > 18 years. Table 1 In 1989, the UN General Assembly adopted the Convention on the Rights of the Child (CRC) within which Article 32 asserts the right that children (below 18 years) should not be engaged in work deemed to be "hazardous or to interfere with the child's education, or to be harmful to the child's health". (United Nations 2008) The percentage of children working in these printing shops is no doubt an obvious violation of child rights as the work in printers is particularly hazardous.

Skin complaints were the main problem mentioned by printing workers participated in this study as $19.3 \%$ reported suffering from skin problems. This result is much lower than that revealed by a study investigated the prevalence of dermatitis in the Nottinghamshire - England printing industry workers where $41 \%$ of respondents reported that they had suffered a skin complaint at some time and $26 \%$ had a current skin problem on the hand. The Nottinghamshire study also showed that all cases of self-reported current skin complaints were confirmed by medical diagnosis indicating high validity of self reported skin complaint (Livesley et al, 2002). The low percentage of workers complaining of skin problems may be because workers consider the changes occurring in their skin as normal and accepted as part of their job.

Back pain was the second complaint reported by workers in the present study (reported by 13.3\%). Back pain in printing industry is due to lifting and transport of heavy loads, or exertions during manual tasks (International Labor organization, 2008). Data from USA showed that printing industry is one of the major industries with the highest average number of workdays lost for each work-related back pain case with an average of 12.1 days lost per case (Guo et al, 1999).

The third health problem reported by workers was the respiratory complaints; reported by $8.9 \%$ of workers. Studies revealed that working in 'printing' industry is positively associated with the occurrence of bronchitis and/or asthma symptoms (Vermeulen et al, 2002). Similarly, High prevalence of self reported respiratory symptoms (cough, phlegm, hemoptysis, dyspnea, wheezing, chest tightness, nose or throat irritation, eye irritation, and sinus trouble) was observed in a study of newspaper pressroom workers exposed to solvents even though the degree of exposure to solvents and lubricants among them was within the current permissible exposure limits (Lee et al 1997). 
Hearing impairment was the least complaint reported by workers as only $4.4 \%$ of the sample complained of hearing impairment believed to be related to their occupation. Again, this self reported percentage is much lower than that observed by a study examined 124 printing workers in Brazil where $49 \%$ of printing workers exposed to noise and organic solvents had hearing loss $(>25 \mathrm{~dB}$ ) in the high frequencies (Morata et al, 2001). Moreover, significantly higher hearing threshold was seen among printing workers from a printing facility at Menoufia University - Egypt compared to controls at frequencies of 1000, 2000, 4000, and 8000 Hz. (Farahat et al 1997).

It should be emphasized that all the previous reported health problems are subjective, thus objective evaluation are needed to determine the actual risk of work- related problems among this group of workers.

Though research revealed that exposure to mixture of organic solvents increase the risk of neurological symptoms among printing workers, and that neurological symptoms were reported by printing workers in various studies, none of the workers in this study reported any neurological symptoms (Yu et al 2004). This finding may be due to unawareness of workers that neurological symptoms such as memory loss and abnormal or reduced smell are related to their occupational hazards.
Printing workers are exposed to injuries such as cuts, amputations and crushing. Injuries can be caused by moving machinery or sharp edges, particularly guillotines (International Labor organization, 2008). This current study revealed that almost 29\% of workers reported being injured during their work, $10 \%$ of workers reported suffering from permanent impairment. Finger amputation was the main reported type of injury. Amputations are clearly one of the most severe types of injuries that can be experienced by an equipment operator and certainly one that can result in permanent disfigurement and disability. Working with equipment within the printing industry can be safe when the equipment used is properly guarded, the right safe work procedures are applied, and the applicable safety rules are followed. Unfortunately, amputations and other serious injuries still occur due to a number of factors, including unsafe work practices, improper guarding, and inadequate procedures during service and maintenance of equipment (Printing Industries of America. 2008).

The present study revealed very low reported compliance with safety measures. The majority of the sample never wore overalls $(82.2 \%)$ or gloves $(92.6 \%)$ during their work. Quite the opposite of this finding, two studies done among printing workers 
in Hong Kong ( $\mathrm{Yu}$ et al 2005) and Nottinghamshire- England showed that $75.6 \%$ and $67 \%$ respectively used gloves while $60 \%$ of Nottinghamshire sample wore overalls (Health and Safety Executive 2008).

None of the workers participated in this study reported wearing ear or eye protectors or respiratory protecting equipment. Comparing this results with that of the Nottinghamshire study showed that ear plugs and glasses were used by $43 \%$ and $19 \%$ of workers respectively (Health and Safety Executive 2008). Higher percentage of using hearing protectors was observed in a study among printing workers in Brazil where $64 \%$ of studied workers indicated that they wore hearing protectors, but only $20 \%$ of this subgroup stated that they wore the device all the time when exposed to noise (Morata et al 2001).

Good ventilation systems in printing industry are essential to decrease workers' exposure to different hazards (World Bank Group 2008 a ). Windows was the only way used for ventilation in the 10 visited printshops. Despite of this, the great majority of the sample (98.4\%) was not keen to open the widows for good ventilation. Table 4 This may be due to unawareness of the importance of good ventilation and their low perceived risk of the vapors of different chemical compounds they are exposed to.
Not eating while working with chemicals and washing hands before eating are essential safety practices that help workers to avoid unnecessary exposure to chemicals (Health and Safety Executive 2008 b). The present study revealed that the majority of the sample (98.5\%) reported eating while working in the print-shop. In the study done in Hong Kong it was found that only 56\% of the sample of printing workers always washed their hands before eating/ or drinking (Yu et al 2005).

Various studies revealed that risk perception in workplaces can influence workers' safety practices and thus their exposure to these risks (Stewart-Taylor and Cherrie 1998, Arezes and Miguel 2005a, Arezes and Miguel 2005b, Arezes and Miguel 2008). The present study revealed that perception of risk was very low for most of the hazards. Those who reported high perception of risk were only $5.2 \%, 7.4 \%, 5.9 \%, 5.9 \%$ and $11.1 \%$ for solvents, ink, adhesives/glue, noise and ultraviolet rays from photocopiers respectively. This low risk perception can explain the unsafe practices reported among this group of workers. Similarly, in a study of the role of risk perception in the use of hearing protection, low scores were obtained for the item "Noise in my workplace is not dangerous" and "It is not needed to use hearing protective devices in 
my workplace". The authors concluded that workers were not exactly aware of the risk they are exposed to and despite there was a need to use hearing protective devices in all the analyzed workplaces, some of the workers saw their workplaces as not significantly dangerous, therefore, a place where it is not necessary to use hearing protective devices (Arezes and Miguel 2005b).

Perception of risk of machinery injury was some what higher than that of other hazards (20.7\% had high perceived risk). This finding can be explained by the fact that the effect of accidents is immediate and visible to all workers, however, the effects of other hazards are "invisible", that is, the damage process is chronic and it does not show immediate effect at the time of exposure.

It is postulated that perceived threat produces a state of readiness to take protective actions among individuals (Janz et al 2002). Moreover, a recent study showed that high perception of threat was associated with workers' readiness to participate in occupational safety programs (Goldberg et al 2006). Unfortunately the results of the present study showed that perceived threat was considered to be high among $17 \%$ only of the sample, while that of $44.4 \%$ was considered low. This inadequate threat perception among workers makes them unmoti- vated to take protective actions. Perceived threat was found to be significantly higher among older workers and those with higher education. As shown in table 6,85.7\% of $<18$ years worker had low perception of threat compared to $34.1 \%$ of workers in the age group $\geq 40$ years. Lack of experience of young workers and not worrying about health consequences may desensitize them to the potential health risks they face. Similarly, age of the worker was an important factor related to use of PPE as participants of focus group discussion reported that younger inexperienced workers were less likely to perceive the risk of eye injury and were less likely to use PPE (Lombardi et al 2009). This is also consistent with the study done by Forrest et al. (2008) that reported that only $15.3 \%$ of those 18-24 years of age reported using eye protection while engaging in activities outside of work that could cause an eye injury. Programs targeting younger workers may be effective in increasing their perception of risk (Lombardi et al 2009). On the contrary, another study showed significant negative correlation between age and risk perception indicating higher risk perception among younger workers (Arezes and Miguel 2005a).

Enhancing perception of threat should be considered in any health education program designed to promote safety practices 
among this group of workers giving special attention to younger and less educated workers.

It is assumed that the worker will follow the recommended safety practices including the use of PPE if he/she expects that these practices will lead to the desired health outcome. Person's belief about the effectiveness of the recommended practices and not the actual facts about the effectiveness determine whether he/she follows the recommended practice or not (Janz et al 2002). Only about one quarter of printing workers in the present study perceive protective behaviors to be highly beneficial, while around half of the sample had low perceived benefits. Thus, emphasis may be needed on raising perceptions of the benefits of protective behaviors. Workers with higher education and those attended safety education / training were found to have higher perception of benefit. This supports the importance of safety training. Similarly, a recent study showed that respondents who reported having safety training were more likely to use PPE (Lombardi et al 2009). Despite the importance of safety training, those who received any safety education or training in the present study represented only around one quarter of the sample. This is expected as training of workers in small enterprises is usually neglected. A recent study revealed that most of the workers reported not having safety training were working for small companies with no formal safety training program (Lombardi et al 2009).

Perception of barriers is considered one of the important concepts of the HBM. The HBM literature suggests that barriers are the single best predictor of health behavior. Relevant to the workplace, research on the use of personal protective equipment shows that job related barriers are often a major factor in noncompliance (DeJoy 1996, Peter and Robyn 2001). The first barrier to use PPE mentioned by $28.1 \%$ of the sample of printing workers was that PPE interfere with job performance followed by feeling uncomfortable while using PPE $(20.7 \%)$. Similarly, in a study done on use of hearing protection devices, interference with communication (can't hear other persons), feeling uncomfortable were the barriers mentioned by $15 \%$ and $14 \%$ of the workers respectively (Arezes and Miguel 2005a). Unavailability of PPE as a barrier to their use was mentioned by $19.3 \%$ of the sample. A recent study concluded that using PPE at work was determined largely by whether they were provided or not (Goldberg et al 2006). Not receiving any training for the use of PPE was the fourth barrier mentioned by $17.8 \%$ of the sample. There- 
fore, attention should be given to the ready availability of safety equipment and devices, and the importance of skill-based training in facilitating self-protective behavior. Actually, efforts to influence workers' perception of threat and benefit and, thus, motivate them to follow safe practices may fail if the environment is non-supportive (PPE are unavailable and not training workers). Overall, perception of barriers is considered low among this group of workers as the majority of workers had either low or moderate perceived barrier while only around one fifth had high barrier perception. The explanation that may be given to this low perceived barrier is that workers in the present study has no experience in following protective behaviors, so they actually can't feel the barriers behind adoption of such behaviors.

\section{Conclusion and recommendations:}

It can be concluded that protective behaviors and perceptions among printing workers are extremely inadequate. The study highlights the importance of effective safety education and training to enhance workers perception of threat and benefit and decrease their perception of barriers. Thus adoption of safety behaviors can be achieved. Special attention should be directed towards young workers and those with lower education.

\section{References:}

1. Al-Hemoud, A. M. and Al-Asfoor, M. M. (2006). A behavior based safety approach at a Kuwait research institution. Journal of Safety Research, 37: 201-206.

2. Arezes, P. M. and Miguel, A. S. (2005a). Individual perception of noise exposure and hearing protection in industry. Human Factors, 47(4):683-692.

3. Arezes, P. M and Miguel, A. S. (2005b). Hearing protection use in industry: The role of risk perception. Safety Science, 43: 253-267.

4. Arezes, P. M and Miguel, A. S. (2008). Risk perception and safety behavior: A study in an occupational environment. Safety Science, 46: 900-907.

5. CDC. Controlling Cleaning-Solvent Vapors at Small Printers. [Cited 2008 September]. Available at: http://www.cdc.gov/niosh/hc24.html

6. CNA. Industry Guide Series. Printing and Graphic Imaging Industry. [Cited 2008 September] Available from: http://www.cna.com/ vcm_content/CNA/internet/Static\%20File\%20 for\%20Download/Risk\%20Control/PGI\%20Industry\%20Guide.pdf

7. Colémont, A. and Van den Broucke, S. (2008) Measuring determinants of occupational health related behavior in Flemish farmers: An application of the Theory of Planned Behavior. Journal of Safety Research, 39: 55-64

8. DeJoy, D. M. (1996) Theoretical models of health behavior and workplace self-protective behavior. Journal of Safety Research, 27 (2): 61-72.

9. Farahat, T. M., Abdel-Rasoul, G. M., El-Assy, A. R., Kandil, S.H.and Kabil, M.K. (1997). Hearing Thresholds of Workers in a Printing Facility. Environmental Research, 73: 189-192.

10. Forrest, K. Y., Cali, J.M. and Cavill WJ. (2008) Use of protective eyewear in U.S. adults: results from the 2002 national health interview survey. Ophthalmic Epidemiol.,15 (1): 37-41. 
11. Gardner, D., Cross, J. A., Fonteyn, P. N., Carlopio, J. and Shikdar, A. (1999). Mechanical equipment injuries in small manufacturing businesses. Safety Science, 33: 1-12

12. Goldberg, A.I., Dar-El, E.M. and Rubin, A.E. (2006). Threat perception and the readiness to participate in safety programs. Journal of organizational behavior, 12 (2): 109-22.

13. Guo, H., Tanaka, S., Halperin, W. E.and Cameron, L.L. (1999). Back pain prevalence in US industry and estimates of lost workdays. Am J Public Health, 89:1029-35.

14. Health and Safety Executive (2008 a). The prevalence of occupational dermatitis amongst printers in the Midlands. Contract Research Report 307/2000. [Cited on 2008 December] Available at: http://www.hse.gov.uk/research/ crr_pdf/2000/crr00307.pdf

15. Health and Safety Executive (2008 b). Working safely with solvents: A guide to safe working practices. [Cited on 2008 December]. Available at: http://www.hse.gov.uk/pubns/indg273.pdf

16. Hoshuyama, T., Hino, Y., Kayashima, K., Morita, T., Goto, H., Minami, M., et al. (2007) Inequality in the health status of workers in small-scale enterprises. Occupational Medicine, 57(2):126-130.

17. International Labor Organization. International Hazard Datasheets on Occupation: Printers. [Cited 2008 September]. Available at: http:// www.ilo.org/public/english/protection/safework/cis/products/hdo/htm/printer.htm

18. Janz, N. K., Champion, V.L. and Strecher, V.J. (2002). The health belief model. In: Glanz, K., Rimer, B., Lewis, S., editors. Health behavior and health education. Theory, research, and practice. 3rd edition. San Francisco, Oxford: Jossey-Bass. A Wiley Imprint; pp. 45-66.

19. Lee, B.W., Kelsey, K.T., Hashimoto, D., Yakes, B., Seitz, T. and Christiani, D.C.(1997). The prevalence of pulmonary and upper respiratory tract symptoms and spirometric test findings among newspaper pressroom workers ex- posed to solvents. J Occup Environ Med., 39 (10):960-969.

20. Livesley, E. J., Rushton, L., English, J.S. and Williams, H.C. (2002). The prevalence of occupational dermatitis in the UK printing industry. Occupational and Environmental Medicine, 59: 487-492.

21. Lombardi, D. A., Verma, S. K., Brennan, M. J. and Perry, M. J. (2009). Factors influencing worker use of personal protective eyewear. Accident Analysis and Prevention, 41: 755-762

22. Morata, T.C., Fiorini, A. C. , Fischer, F. M., Krieg, E. F., Gozzoli, L. and Colacioppo, S. (2001). Factors affecting the use of hearing protectors in a population of printing workers. Noise Health., 4(13):25-32.

23. Nelson, D. I., Nelson, R.Y., Concha-Barrientos, M. and Fingerhut, M. (2005). The global burden of occupational noise-induced hearing loss. Am J Ind Med., 48(6):446-458.

24. Peter, R. M. and Robyn, D. (2001). Is acculturation related to use of hearing protection? American Industrial Hygiene Association journal, 62 (5): 611-614.

25. Printing Industries of America. Reducing amputation risks in the commercial lithographic printing industry. [Cited on 2008 December] Available from: http://www .printing.org/page/4494

26. Stewart-Taylor, A. and Cherrie, J.W. (1998). Does risk perception affect behavior and exposure. A pilot study amongst asbestos workers. Annals of Occupational Hygiene, 42 (8), 565-569.

27. United Nations. Convention on the Rights of the Child. UN General Assembly resolution 44/25 of 20 November 1989. [Cited on 2008 December] Available at: http://www.un.org/ documents/ga/res/44/a44r025.htm

28. Vermeulen, R., Heederik, D., Kromhout, H.and Smit, H. A. (2002). Respiratory symptoms and occupation: a cross-sectional study of the general population. Environ Health. 2002; 1(1): 5-11. 
29. World Bank Group. Environmental, health, and safety guidelines for printing. [Cited on 2008 December]. Available at:http://www.ifc. org/ifcext/enviro.nsf/AttachmentsByTitle/gui_ EHSGuidelines2007_Printing/\$FILE/Final++Printing.pdf

30. Yu, I. T., Lee, N. L., Zhang, X. H., Chen, W. Q., Lam, Y. T. and Wong, T.W. (2004) Oc- cupational exposure to mixtures of organic solvents increases the risk of neurological symptoms among printing workers in Hong Kong. J Occup Environ Med., 46(4):323-330.

31. Yu, I. T., Lee, N. L. and Wong, T. W. (2005) Knowledge, attitude and practice regarding organic solvents among printing workers in Hong Kong. J Occup Health., 47 (4):305-310. 